Удк 616-089+616.61+616.14

DOI 10.11603/2414-4533.2019.4.10717

(CI. І. КОБЗА ${ }^{1}$, І. Р. НЕСТЕРЕНКО ${ }^{2}$, В. Л. НЕСТЕРЕНКО ${ }^{2}$, А. Т. КІХТЯК ${ }^{3}$, Л. Ю. ГРЕЧУХ

Львівський національний медичний університет імені Данила Галицького ${ }^{1}$

Івано-Франківський національний медичний університет ${ }^{2}$

Львівська обласна клінічна лікарня ${ }^{3}$

\title{
Віддалені результати хірургічного лікування синдрому аорто- мезентеріальної компресії
}

\begin{abstract}
Мета роботи: дослідити віддалені наслідки реімплантації лівої ниркової вени.
Матеріали і методи. 31999 по 2019 рр. обстежено 146 пацієнтів віком від 14 до 34 років з підозрою на “синдром лускунчика”. В дослідження увійшли пацієнти з явищами гематурії, протеїнурії, лівобічного варикоцеле, лівобічного пудендального варикозу та болем в лівій половині живота нез'ясованої етіології. Всім хворим проведено ультразвукову кольорову доплерографію нирок, ниркових та гонадних вен. У 81 пацієнта за даними УЗД діагностовано різний ступінь аорто-мезентеріальної компресії (55,4 \%). 11-ти пацієнтам із критичним стенозом лівої ниркової вени проведено реімплантацію лівої ниркової вени.

Результати досліджень та їх обговорення. Віддалені результати вивчені в строки від від 6 до 20 років після операції. На огляд 3'явились 8 пацієнтів. Всі опитані пацієнти вказували на зникнення болю в лівій половині живота, гематурії (лише один пацієнт вказував на рецидив гематурії, що з’явилась через 5 років після оперативного лікування), у всіх пацієнтів відсутній рецидив варикоцеле. При проведенні УЗД-контролю місця реконструкції у 4-х пацієнтів стенозу місця реконструкції не виявлено, у 4-х пацієнтів виявлено некритичний стеноз місця реконструкції (до 50 \%).
\end{abstract}

Ключові слова: аорто-мезентеріальна компресія; критичний стеноз лівої ниркової вени; реімплантація лівої ниркової вени.

Постановка проблеми і аналіз останніх досліджень та публікацій. “Синдром лускунчика” - рідкісний феномен, який виникає при компресії лівої ниркової вени між аортою та верхньою брижовою артерією, що призводить до розвитку флебогіпертензії в лівій нирковій вені [1, 2].

Анатомічними передумовами виникнення “синдрому лускунчика” $є$ відходження верхньої брижової артерії від аорти під гострим кутом, що спричиняє компресію лівої ниркової вени. В нормі верхня брижова артерія відходить від аорти під прямим кутом, направляється вентрально протягом 4-5 мм, після чого опускається каудально. Ця анатомічна особливість запобігає стисненню лівої ниркової вени верхньою брижовою артерією, натомість при “синдромі лускунчика” кут відходження верхньої брижової артерії гострий і становить зазвичай $38-56^{\circ}[1]$.

Перший опис даної аномалії здійснив анатом Grant y 1937 p. Клінічно дана нозологія була описана лікарем El.-Sadr.A.R., Mina E. в 1950 р. [3], а в 1971 р. бельгійський лікар De Schepper порівняв аорту і верхню брижову артерію з щелепами “лускунчика”, який стискає ліву ниркову вену [3].

Золотим стандартом діагностики синдрому “лускунчика” є проведення флебографії з флеботонометрією з визначенням градієнта тиску між нижньою порожнистою веною та лівою нирковою веною, проте через інвазивність, вартість і тривалість даної процедури методом вибору є ультразвуко- ва кольорова доплерографія, інформативність якої становить за різними даними 78-100 \% [4].

Патогенетично обгрунтованим хірургічним лікуванням “синдрому лускунчика” $\epsilon$ транспозиція лівої ниркової вени, яка дозволяє ліквідувати гіпертензію в лівій нирковій вені [5], вона проводиться ізольовано чи в поєднанні з накладанням проксимальних чи дистальних ілеотестикулярних анастомозів (за Лопаткіним) залежно від типу рефлюксу по Coolsaet.

Мета роботи: дослідити віддалені наслідки реімплантації лівої ниркової вени.

Матеріали і методи. 31999 по 2019 рр. на базі Львівської обласної клінічної лікарні, ІваноФранківської обласної клінічної лікарні, медичних центрів імекс - “Соно”, “Триомед”, “Cedrus”, “КоронаМед” (м. Львів) та медичного центру “Ciмедгруп” (м. Івано-Франківськ) обстежено 146 пацієнтів з підозрою на “синдром лускунчика”. В дослідження увійшли пацієнти з явищами гематуpiї, протеїнурії, лівобічного варикоцеле, лівобічного пудендального варикозу та болем в лівій половині живота нез'ясованої етіології. Вік пацієнтів становив від 14 до 34 років.

Всім хворим проведено ультразвукову кольорову доплерографію нирок, ниркових та гонадних вен на ультразвукових апаратах Esaote Technos (Італія), Acuson 128 XP (США), Aloka SSD 3500 (Японія), Siemens Acuson X700 в реальному масш- 
табі часу, в режимі сірої шкали, а також в режимі кольорового доплерівського картування. Використовували секторальні та лінійні матричні датчики 3,5-12 МГц.

За даними УЗД нирок, ниркових та гонадних вен оцінювали розмір, розташування, рухомість, наявність змін у паренхімі нирок, діаметр і розташування ниркових і гонадних вен, швидкісні характеристики та наявність патологічних рефлюксів, звертаючи особливу увагу на різницю діаметрів лівої ниркової вени в дистальній частині та в аорто-мезентеріальному сегменті, а також на різницю між піковими швидкостями кровотоку в даних ділянках.

У 81 пацієнта згідно з даними УЗД діагностовано різний ступінь аорто-мезентеріальної компресії (55,4 \%).

Для ультразвукової картини “синдрому лускунчика” характерне різке звуження діаметра лівої ниркової вени в аорто-мезентеріальному сегменті та постстенотичне розширення в дистальній частині, що корелювало з відповідним зростанням пікової систолічної швидкості у стенозованій частині лівої ниркової вени (рис. 1).

Згідно зі спостереженнями, клінічні прояви “синдрому лускунчика” виникають при збільшенні діаметра дистальної (постстенотичної) частини лівої ниркової вени порівняно з проксимальним (аорто-мезентеріальним ) її сегментом у 3-6 разів (в середньому - у 4,3 раза), а також зростання пі-

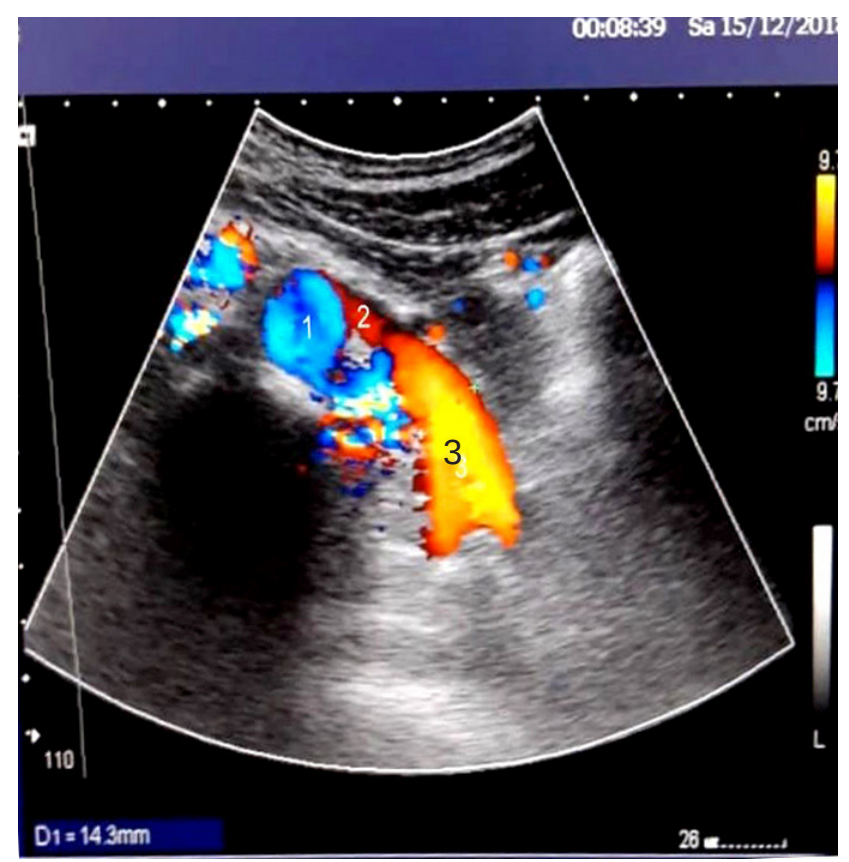

Рис. 1. УЗД-картина “синдрому лускунчика”(1 аорта, 2 - стенозована частина ЛНВ, 3 - дилатована частина ЛНВ ). кової систолічної швидкості в стенозованому проксимальному (аорто-мезентеріальному) сегменті у 6-14 разів (в середньому - у 8,7 раза) порівняно 3 дистальним сегментом лівої ниркової вени. Показники співвідношення діаметрів дистального і проксимального сегментів лівої ниркової вени $\geq 3$ та співвідношення пікових систолічних швидкостей у проксимальному та дистальному сегментах $\geq 6$ ми оцінювали як критичний стеноз лівої ниркової вени, що потребував хірургічної корекції.

Пацієнтів розподілено на 3 групи: 1-ша група - хворі без ультразвукових ознак аорто-мезентеріальної компресії, 2-га група - 3 діагностованою аорто-мезентеріальною компресією з гемодинамічно незначним стенозом лівої ниркової вени, 3-тя група - з критичним стенозом лівої ниркової вени, результати представлено на рисунку 2.

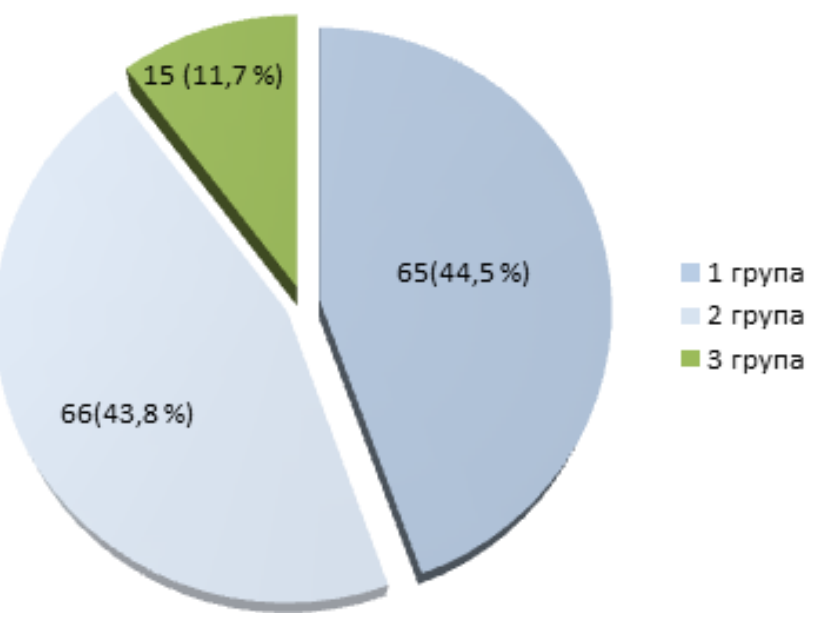

Рис. 2. Розподіл пацієнтів за ультразвуковими ознаками аорто-мезентеріальної компресії.

Оцінювали ультразвукові доплерографічні параметри лівої ниркової вени пацієнтів 3-х груп, дані представлено в таблиці 1.

Оцінювали ультразвукові доплерографічні параметри лівої гонадної вени та наявність в ній патологічних рефлюксів у пацієнтів 3-х груп, дані представлені в таблиці 2.

У групі пацієнтів 3 критичним стенозом лівої ниркової вени на УЗД нирок діагностовано повнокрів’я лівої нирки, дилатацію ниркових вен та явища венозного застою лівої нирки.

15-ти хворим із критичним стенозом лівої ниркової вени запропоновано оперативне лікування, 3 них - 4 пацієнти відмовились від операції, 11-ти пацієнтам проведено реімплантацію лівої ниркової вени ізольовано, або у поєднанні з накладан- 
Таблиця 1. Доплерографічні ультразвукові параметри лівої ниркової вени у пацієнтів 3-х груп

\begin{tabular}{|c|c|c|c|c|}
\hline Параметри & $\begin{array}{c}\text { Група без Уз- } \\
\text { ознак аорто- } \\
\text { мезентеріальної } \\
\text { компресії, n=65 }\end{array}$ & $\begin{array}{c}\text { Група з аорто-мезентеріальною } \\
\text { компресією з гемодинамічно } \\
\text { незначним стенозом лівої } \\
\text { ниркової вени, n=66 }\end{array}$ & $\begin{array}{c}\text { Група з критичним } \\
\text { стенозом лівої } \\
\text { ниркової вени, } \\
\text { n=15 }\end{array}$ & $\mathrm{p}$ \\
\hline \multicolumn{5}{|c|}{ Діаметр, мм } \\
\hline Ворота нирки & $6,1 \pm 0,87$ & $10,4 \pm 1,13$ & $12,2 \pm 1,87$ & $<0,001$ \\
\hline $\begin{array}{l}\text { Аорто- } \\
\text { мезентеріальний } \\
\text { сегмент }\end{array}$ & $3,9 \pm 0,5$ & $3,3 \pm 0,43$ & $3,0 \pm 0,96$ & $<0,001$ \\
\hline \multicolumn{5}{|c|}{ Пікова швидкість кровотоку, см/с } \\
\hline Ворота нирки & $28 \pm 1,9$ & $30 \pm 0,94$ & $21,6 \pm 0,75$ & $<0,001$ \\
\hline $\begin{array}{l}\text { Аорто- } \\
\text { мезентеріальний } \\
\text { сегмент }\end{array}$ & $34 \pm 1,45$ & $84 \pm 0,86$ & $178,3 \pm 1,93$ & $<0,001$ \\
\hline
\end{tabular}

Таблиця 2. Доплерографічні ультразвукові параметри лівої гонадної вени та наявність у ній патологічних рефлюксів у пацієнтів 3-х груп

\begin{tabular}{||l|c|c|c|c||}
\hline \hline \multicolumn{1}{|c||}{ Параметри } & $\begin{array}{c}\text { Група без Уз- } \\
\text { ознак аорто- } \\
\text { мезентеріальної } \\
\text { компресії, } \mathrm{n=65}\end{array}$ & $\begin{array}{c}\text { Група з аорто-мезентеріальною } \\
\text { компресією лівої ниркової вени } \\
\text { 3 гемодинамічно незначним } \\
\text { стенозом, } \mathrm{n}=66\end{array}$ & $\begin{array}{c}\text { Група з критичним } \\
\text { стенозом лівої } \\
\text { ниркової вени, } \\
\mathrm{n}=15\end{array}$ & $\mathrm{p}$ \\
\hline $\begin{array}{l}\text { Діаметр лівої } \\
\text { гонадної вени, мм }\end{array}$ & $2,9 \pm 0,6$ & $4,2 \pm 0,84$ & $6,5 \pm 1,1$ & $<0,001$ \\
\hline $\begin{array}{l}\text { Наявність } \\
\text { патологічних } \\
\text { рефлюксів у } \\
\text { гонадній вені }\end{array}$ & $\begin{array}{c}\text { патологічні } \\
\text { рефлюкси } \\
\text { відсуті }\end{array}$ & $\begin{array}{c}\text { патологічні рефлюкси відсутні } \\
\text { або }+1\end{array}$ & $+2 /+3$ & \\
\hline
\end{tabular}

ням тестикуло-ілеакальних анастомозів (проксимальних або дистальних) залежно від типу рефлюксу за Coolsaet (рис. 3, 4). Реімплантацію лівої

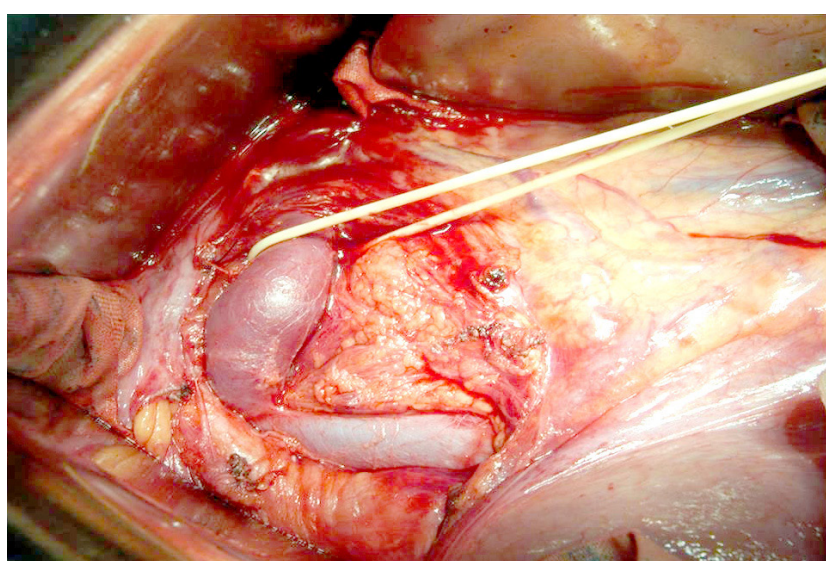

Рис. 3. Дилатована ліва ниркова вена (взята на трималку). ниркової вени проводили шляхом серединної лапаротомії, виділяли ліву ниркову вену в місці їі впадання в нижню порожнисту вену, відсікали та

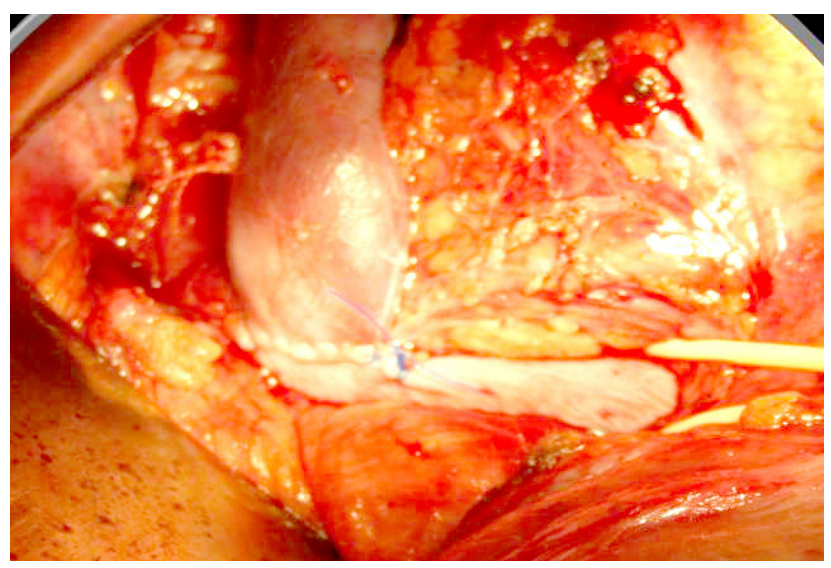

Рис. 4. Місце анастомозу (реімплантована ліва ниркова вена, трималка на нижній порожнистій вені). 
реімплантували нижче на 2-4 см від місця аортомезентеріальної компресії. Гемостаз. Пошарові шви на рану.

У 3-х пацієнтів реімплантацію лівої ниркової вени доповнювали накладанням тестикуло-ілеакального анастомозу через виражений патологічний рефлюкс по лівій гонадній вені (рис. 5).

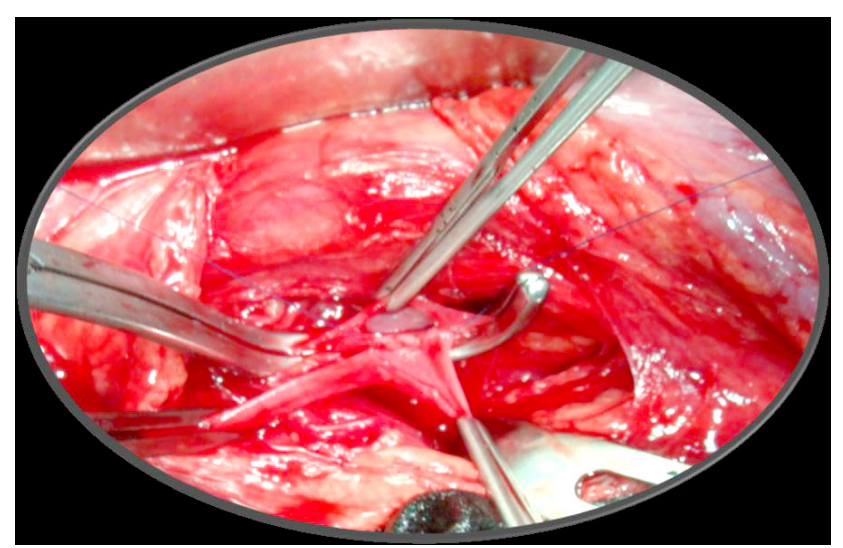

Рис. 5. Накладання тестикуло-ілеакального анастомозу.

Ранній післяопераційний період перебігав без ускладнень. Хворих виписали на 7-9 доби з рекомендаціями приймання ривароксабану.

Результати досліджень та їх обговорення. Віддалені результати вивчено в строки від від 6 до 20 років. Для аналізу віддалених результатів всім хворим рекомендовано контрольний огляд, що включав опитування пацієнта, об’єктивний статус та проведення ультразвукової кольорової доплерографії місця реконструкції, лівої ниркової та гонадної вен та лівої нирки.

На огляд з'явились 8 пацієнтів. Всі опитані пацієнти вказували на зникнення болю в лівій половині живота, зникнення гематурії (лише один пацієнт вказував на рецидив гематурії, що з'явилась через 5 років після оперативного лікування, дообстежується на предмет інших причин гематурії), протеїнуpiї. Об’єктивно: у всіх пацієнтів відсутній рецидив варикоцеле. При проведенні УЗД-контролю місця реконструкції у 4-х пацієнтів стенозу місця реконструкції не виявлено, у 4-х пацієнтів встановлено некритичний стеноз місця реконструкції (до 50 \%), проте венозний відтік по лівій нирковій вені не порушений, відсутній перепад пікових систолічних швидкостей в сегментах лівої ниркової вени.

Транспозиція лівої ниркової вени вперше була виконана в 1982 р. Stewart і передбачала від’єднання лівої ниркової вени від нижньої по- рожнистої вени, ушивання дефекту нижньої порожнистої вени та реанастомоз нижче верхньої брижової артерії. До переваг методу відносили короткий період ниркової ішемії, до недоліків ризик тромбозу лівої ниркової вени, кровотечі, парезу кишечника [5].

Не зважаючи на спроби урізноманітнення хірургічної корекції даної патології (транспозиція верхньої брижової артерії, лапароскопічне екстраваскулярне стентування, ендоваскулярне стентування та ін.) найкращі результати у віддаленому післяопераційному періоді демонструє саме транспозиція лівої ниркової вени [5]. Після перших опублікованих результатів лікування “синдрому лускунчика” дещо зросла активність щодо виявлення та діагностики даного захворювання, проте через неспецифічність симптомів, відсутність діагностичних алгоритмів та низьку обізнаність лікарів “синдром лускунчика” все ще належить до рідко діагностованих патологій. На сьогодні в літературі описано всього 112 випадків хірургічного лікування “синдрому лускунчика” згідно з даними Mayo Clinic [3]. До країн з найбільшою частотою виявлення “синдрому лускунчика” відносять країни Північної Америки та Західної Європи, проте такий розподіл епідеміологічних даних пов'язаний, ймовірно, 3 вищою інформованістю та настороженістю лікарів стосовно даного діагнозу $[6,7,8]$. В Україні ж ситуація 3 виявлення, діагностики та лікування даного захворювання залишається проблематичною. В 2018 р. вперше в пресі з'явилось повідомлення про ендоваскулярне лікування “синдрому лускунчика” в м. Запоріжжя (проф. А. О. Никоненко): трьом пацієнтам було проведено успішне стентування лівої ниркової вени [Три операции за два дня провели в Запорожской области при участии польских сосудистых хирургов [Електронний ресурс] // Индустриалка. - 2018. - Режим доступу до ресурсу: http://iz.com.ua/zdorovye/v-zaporozheproveli-unikalnuyu-v-ukraine-operatsiyu].

31999 р. на базі Львівської обласної клінічної лікарні прооперовано 10 пацієнтів 3 “синдромом лускунчика” за участю проф. Кобзи I. I.) [ 30-річному чоловікові п’ять років не могли поставити правильний діагноз [Електронний ресурс] // TheWorldNews.net. - 2019. - Peжим доступу до ресурсу: https://theworldnews.net/ ua-news/30-richnomu-cholovikovi-p-iat-rokiv-nemogli-postaviti-pravil-nii-diagnoz.]. Таким чином, відсоток оздоровлення хворих із даною патологією залишається вкрай низьким, а прояви “синдрому лускунчика”, зокрема, варикоцеле, становлять значну проблему через високу частоту реци- 
дивів після операції Іваніссевича (від 8,6 до 25 \%) оскільки дане втручання не ліквідовує головний патогенетичний механізм виникнення варикоцеле при цьому захворюванні - флебогіпертензію в лівій нирковій вені [7].

\section{СПИСОК ЛІТЕРАТУРИ}

1. Imaging findings and clinical features of abdominal vascular compression syndromes / J. K. Fong, A. C. Poh, A. G. Tan, R. Taneja // AJR Am. J. Roentgenol. - 2014. - Vol. 203. - P. 29-36.

2. Nutcracker syndrome - How well do we know it? / Y. He, Z. Wu, S. Chen [et al.] // Urology. - 2014. - Vol. 83. - P. 12-17.

3. Kurklinsky A. K. Nutcracker phenomenon and nutcracker syndrome / A. K. Kurklinsky, T. W. Rooke // Mayo Clin. Proc. 2010. - Vol. 85. - P. 552-559.

4. Diagnosis of the nutcracker syndrome with color Doppler sonography: correlation with flow patterns on retrograde left renal venography / S. Takebayashi, T. Ueki, N. Ikeda, A. Fujikawa // AJR Am. J. Roentgenol. - 1999. - Vol. 172. - P. 39-43.

5. Transposition of the left renal vein for treatment of the
Висновки. Аналіз віддалених результатів хірургічного лікування “синдрому лускунчика” демонструє високу ефективність реімплантації лівої ниркової вени як патогенетично обгрунтованого методу лікування флебогіпертензії.

nutcracker phenomenon: long-term follow-up / M. Hohenfellner, G. D’Elia, C. Hampel [et al.] // Urology. - 2002. - Vol. 59. P. 354-357.

6. Mahmood S. K. An easily missed diagnosis: flank pain and nutcracker syndrome / S. K. Mahmood, G. R. Oliveira, R. P. Rosovsky // BMJ Case Rep. - 2013. - Vol. 37. - P. 415-418. 7. Left renal vein transposition for nutcracker syndrome / N. R. Reed, M. Kalra, T. C. Bower [et al.] // J Vasc Surg. 2009. - Vol. 49. - P. 386-393.

8. A systematic review on management of nutcracker syndrome / C. A. Velasquez, A. Saeyeldin, M. A. Zafar [et al.] // J. Vasc. Surg. Venous Lymphat. Disord. - 2018. - Vol. 6. - P. 271-278.

\section{REFERENCES}

1. Fong, J.K., Poh, A.C., Tan, A.G., \& Taneja, R. (2014). Imaging findings and clinical features of abdominal vascular compression syndromes. AJR Am. J. Roentgenol, 203, 29-36.

2. He, Y., Wu, Z., Chen, S., Tian, L., Li, D., Li, M., ..., \& Zhang, H. (2014). Nutcracker syndrome - How well do we know it? Urology, 83, 12-17.

3. Kurklinsky, A.K., \& Rooke, T.W. (2010). Nutcracker phenomenon and nutcracker syndrome. Mayo Clin. Proc., 85, 552-559.

4. Takebayashi, S., Ueki, T., Ikeda, N., \& Fujikawa, A. (1999). Diagnosis of the nutcracker syndrome with color Doppler sonography: correlation with flow patterns on retrograde left renal venography. AJR Am. J. Roentgenol., 172, 39-43.

5. Hohenfellner, M., D’Elia, G., Hampel, C., Dahms, S., \&

Thüroff, J.W. (2002). Transposition of the left renal vein for treatment of the nutcracker phenomenon: long-term followup. Urology, 59, 354-357.

6. Mahmood, S.K., Oliveira, G.R., \& Rosovsky, R.P. (2013). An easily missed diagnosis: flank pain and nutcracker syndrome. $B M J$ Case Rep., 37, 415-418.

7. Reed, N.R., Kalra, M., Bower, T.C. Vrtiska, T.J., Ricotta, J.J. 2nd, \& Gloviczki, P. (2009). Left renal vein transposition for nutcracker syndrome. J. Vasc. Surg., 49, 386-393.

8. Velasquez, C.A., Saeyeldin, A., Zafar, M.A., Brownstein, A.J., \& Erben, Y. (2018). A systematic review on management of nutcracker syndrome. J. Vasc. Surg. Venous Lymphat. Disord., 6, 271-278.

Отримано 30.10.2019

\section{I. KOBZA ${ }^{1}$, I. R. NESTERENKO ${ }^{2}$, V. L. NESTERENKO², A. T. KIKHTIAK ${ }^{3}$, L. YU. HRECHUKH ${ }^{3}$}

Danylo Halytskyi Lviv National Medical University ${ }^{1}$

Ivano- Frankivsk National Medical University²

Lviv Regional Clinical Hospital ${ }^{3}$

\section{REMOTE RESULTS OF THE NUTCRACKER SYNDROME SURGICAL TREATMENT}

The aim of the work: to evaluate the remote results in the surgical treatment of the nutcracker syndrome.

Materials and Methods. 146 patients with suspected nutcracker syndrome (pain in the left lumbar region, hematuria, left sided varicocele in men, and pudendal varicosity in women) underwent the examination from 1999 to 2019. The patients' age ranged from 14 to 34 years. All patients underwent color Doppler ultrasonography to define the presence of pathological refluxes in the left renal and gonadal veins with the measurement of peak systolic velocity. According to color Doppler ultrasonography, different degree of aorta mesenteric compression was confirmed in 81 (55.4\%) patients, 11 patients with critical stenosis underwent the left renal vein reimplantation. 
Results and Discussion. Assessment of the effectiveness of the left renal vein reimplantation in the remote postoperative period (from 6 to 20 years): 8 patients underwent ultrasound control examination of the reconstruction site, restenosis was not detected in 4 patients, hemodynamically insignificant stenosis of the left renal vein (less than $50 \%$ ) without venous outflow impairment was noted in 4 patients. All of the examined patients indicated disappearance of the pain in the left lumbar region, disappearance of hematuria, recurrence of varicocele was not observed in all patients.

Key words: aorta mesenteric compression; critical stenosis of left renal vein; the left renal vein reimplantation.

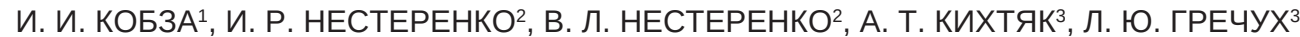

Львовский национальный медицинский университет имени Данила Галицкого ${ }^{1}$

Ивано-Франковский национальный медицинский университет ${ }^{2}$

Львовская областная клиническая больница ${ }^{3}$

\section{ОТДАЛЕННЫЕ РЕЗУЛЬТАТЫ ХИРУРГИЧЕСКОГО ЛЕЧЕНИЯ СИНДРОМА АОРТО- МЕЗЕНТЕРИАЛЬНОЙ КОМПРЕССИИ}

Цель работы: исследовать отдаленные результаты операции реимплантации левой почечной вены.

Материалы и методы. С 1999 по 2019 годы обследовано 146 пациентов в возрасте от 14 до 34 лет с подозрением на “синдром щелкунчика”. В исследование включены пациенты с явлениями гематурии, протеинурии, левостороннего варикоцеле, левостороннего пудендального варикоза и болью в левой половине живота неясной этиологии. Всем больным проводили ультразвуковую цветную допплерографию почек, почечных и гонадных вен. У 81 пациента по данным УЗИ диагностирована аорто-мезентериальная компрессия разной степени (55,4 \%). 11-ти пациентам с критическим стенозом левой почечной вены проведена реимплантация левой почечной вены.

Результаты исследований и их обсуждение. Отдаленные результаты изучены в сроки от 6 до 20 лет после операции. На осмотр явились 8 пациентов. Все обследованные пациенты указывали на исчезновение боли в левой половине живота, гематурии (только один пациент жаловался на рецедив гематурии, которая возникла через 5 лет после оперативного лечения), у всех пациентов отсуствие рецидива варикоцеле. При проведении УЗД-контроля места реконструкции у 4-х пациентов стеноза места реконструкции не обнаружено, у 4-х пациентов обнаружен некритический стеноз места реконструкции (до 50 \%).

Ключевые слова: аорто-мезентериальная компрессия; критический стеноз левой почечной вены; реимплантация левой почечной вены. 